\title{
MECHANICAL BEHAVIOR AND THERMAL STABILITY OF EVA ENCAPSULANT MATERIAL USED IN PHOTOVOLTAIC MODULES
}

\author{
Radek Polanský ${ }^{*}$ _ Martina Pinkerová ${ }^{* *}$ \\ Monika Bartůn̆ková ${ }^{* *}$ _ Pavel Prosr ${ }^{*}$
}

\begin{abstract}
The mechanical behavior and the thermal stability of an encapsulant based on ethylene-vinyl acetate (EVA) were studied. The EVA properties were verified at temperatures ranging from $-70^{\circ} \mathrm{C}$ to $500{ }^{\circ} \mathrm{C}$. Thermogravimetry, differential scanning calorimetry and dynamic mechanical analysis were used in this study. It has been shown that the encapsulant has a good weight stability; however, the encapsulant passes through both a glass transition and a melting phase in the range of operating temperatures. The kinetic parameters of crosslinking were also analyzed. It is possible to achieve $65 \%$ crosslinking at a temperature of $150^{\circ} \mathrm{C}$ and a time of 5 minutes. The activation energy of crosslinking is $95.6 \mathrm{~kJ} / \mathrm{mol}$.
\end{abstract}

K e y w ord s: renewable energy resources, photovoltaic, EVA, encapsulant, glass transition, thermal analysis

\section{INTRODUCTION}

Renewable energy resources are an integral part of our lives. As one of these resources, solar energy does not function without reliable photovoltaic modules. Nowadays, publications concerning photovoltaic modules mostly deal with the manufacturing and optimizing of silicon layers $[1,2]$, rising efficiency of solar energy transformation $([3,4]$ and many others) or ways to decrease manufacturing costs eg. Espinosa et al [5], Kalowekamo and Baker [6]. Little interest is paid to the reliability of these modules $[7,8]$. Considering that manufacturers usually guarantee module lifetime at the least for 20 years, it is necessary to take this lifetime into account and focus on used materials and performance. One key component of photovoltaic modules that influences total reliability is the encapsulant material [9]. Therefore, the main aim of the paper is to analyze mechanical properties together with the thermal stability of an ethylene-vinyl acetate (EVA) film widely used for encapsulation of photovoltaic modules.

\section{BACKGROUND}

The typical photovoltaic module consists of several main layers (see Fig. 1). The part that attracts the most attention is the solar cell itself. The cell is notably brittle under common environmental exposure; therefore, it is necessary to protect the cell during its operation $[10,11]$. It is obvious from Fig. 1 that the solar cell is shielded on the front from mechanical stress (ie, stress during transport, installation or operation stress - wind blast, hailstones or dust influence) by the protective glass sheet. On the backside, the cell is backed with a protective sheet made mostly of plastics.

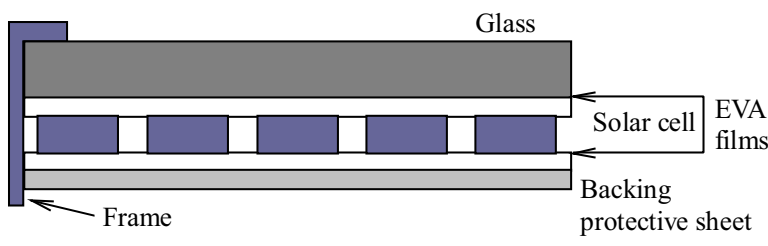

Fig. 1. Schematic drawing of photovoltaic module (cross-section)

All parts are hermetically sealed to one compact unit using two layers of the aforementioned EVA film. This film is absolutely essential from an operational point of view; the film not only protects the solar cell from atmospheric influences, but the film also protects the cell from the influence of vibrations and humidity. The EVA film is placed on the whole surface of the front and back side of photovoltaic module.

Considering that sunray must first pass through the glass sheet and subsequently through the EVA film prior to incidence on the solar cell itself, it is important to discuss the properties of these sheets in greater detail. Regarding reliability, the focus is mainly on the organic component, namely, ethylene-vinyl acetate. This component's properties, processing and mechanisms of degradation have been already described by Czanderna and Pern [10], Klemchuk et al [9], Agroui et al [12,13] and Kempe et al [14]. Most authors agree that the utility of EVA with respect to encapsulation is more a matter of low price than it is a favorable combination of properties.

\section{EXPERIMENTAL PROCEDURE}

\subsection{Materials}

A commercially available encapsulant (VISTASOLAR®, ETIMEX Solar GmbH, Dietenheim, Germany) based on

\footnotetext{
University of West Bohemia, Faculty of Electrical Engineering, Plzeň, Czech Republic, ${ }^{*}$ Regional Innovation Centre for Electrical Engineering, rpolansk@ket.zcu.cz; ${ }^{* *}$ Department of Technologies and Measurement
} 


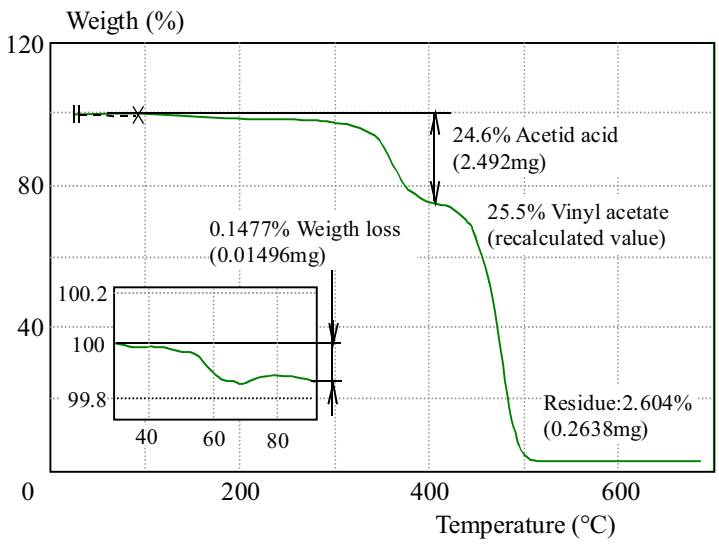

Fig. 2. Determination of vinyl acetate content of EVA by TG

ethylene-vinyl acetate for solar cells was tested. This encapsulant is a thin film that is approximately $0.5 \mathrm{~mm}$ in thickness. With respect to the material sheet, the tested material is a fast-cure EVA, and for proper crosslinking, a temperature of $150^{\circ} \mathrm{C}$ for 13 to 20 minutes in vacuum is necessary (including $3-5$ minutes of pumping time and 10-15 minutes of lamination). Both the uncrosslinked and crosslinked materials were tested. The uncrosslinked encapsulant was exposed to a temperature of $150{ }^{\circ} \mathrm{C}$ for 15 minutes (including 5 minutes to permit evacuation and adhesion and 10 minutes of lamination) and a pressure that was slowly reduced from $950 \mathrm{mBar}$ to $300 \mathrm{mBar}$ during crosslinking.

\subsection{Methods}

Thermogravimetry (TG) has been utilized for determining the vinyl acetate content of the EVA encapsulant and its weight stability. The sample $(12 \mathrm{mg})$ was placed in an open platinum cup and exposed to a linear heating rate of $10^{\circ} \mathrm{C} / \mathrm{min}$ starting from ambient conditions $\left(30^{\circ} \mathrm{C}\right)$ and increasing to $700^{\circ} \mathrm{C}$ in a dry-air atmosphere.

Differential scanning calorimetry (DSC) has been used for the kinetic analysis of crosslinking and to analyze the EVA melting behavior. Kinetic analyses were conducted at four heating rates $\left(2.5,5,10\right.$ and $\left.20^{\circ} \mathrm{C} / \mathrm{min}\right)$ in a nitrogen atmosphere while the samples $(10 \mathrm{mg})$ were placed in hermetic aluminum cups. The measurement and calculation of kinetic parameters was performed in accordance with ASTM E698E-05 [15]. The DSC analysis of EVA melting was measured in a dry-air atmosphere in open platinum cups (using a sample weight of $12 \mathrm{mg}$ ). The TG and DSC data were collected using a simultaneous TG/DSC apparatus SDT Q600 manufactured by TA Instruments.

A thermomechanical analyzer, TMA Q400EM (TA Instruments), allowing DMA mode was utilized for dynamic mechanical analysis (DMA). Measurements proceeded in penetration mode. A static force of $0.3 \mathrm{~N}$ was applied to the sample, and the amplitude of oscillating force was $+/-0.2 \mathrm{~N}$ at a frequency of $1 \mathrm{~Hz}$. The sample was exposed to a linear heating rate of $5{ }^{\circ} \mathrm{C} / \mathrm{min}$ starting from
$-70{ }^{\circ} \mathrm{C}$ and increasing to $200{ }^{\circ} \mathrm{C}$ in a dry-air atmosphere. Circle-shaped samples were prepared by cutting the EVA film for use in all of the aforementioned methods.

\section{RESULTS AND DISCUSSION}

\subsection{Preliminary measurements}

First, a series of preliminary measurements on crosslinked and uncrosslinked EVA foil samples were performed. TG analysis was used to examine the weight stability of crosslinked EVA and to determine the approximate vinyl acetate content. The thermogravimetry results are presented in Fig. 2. The analysis demonstrated the good weight stability of crosslinked EVA over temperatures ranging from $25^{\circ} \mathrm{C}$ to $90^{\circ} \mathrm{C}$ (weight loss of $0.14 \%$ ). This result confirms that the crosslinking was performed correctly, as well as a good future weight stability in the interval of higher operational temperatures.

Similar results were obtained, eg, by Agroui et al [12]. It has also been shown by TG that the EVA supplied contains $25.5 \%$ of vinyl acetate (where residue at the end of the measurement has been considered in the calculation). A measured content of vinyl acetate $32.5 \%$ is presented at nitrogen atmosphere by Klemchuk et al [9].

A kinetics analysis of the crosslinking process was performed to understand crosslinking dynamics and for a contingent optimization of the crosslinking process. Measurement and calculation of Arrhenius kinetic parameters was performed in accordance with ASTM E698E-05 [15]. First, the crosslinking reaction of uncrosslinked EVA foil was recorded at different heating rates by DSC (Fig. 3), and temperatures at which the reaction peak maxima occur are subsequently plotted as a function of their respective heating rates and kinetic values (activation energy and pre-exponential factor) calculated from the peak temperature-heating rate relationship are used to predict reaction half-life at a selected temperature.

The percent of conversion as a function of time at different temperatures $\left(120-190^{\circ} \mathrm{C}\right)$ is plotted in Fig. 4 . It is obvious that the crosslinking reaction is notably fast.

Agroui et al [13] recommend a minimum acceptable conversion level (EVA gel content) of $65 \%$ with reference to work performed at Springborn Laboratory. Manufacturers of photovoltaic modules follow the same rule, and $65 \%$ conversion is considered to be satisfactory. This level is marked in Fig. 4 and is achieved in 5 minutes at a temperature of $150^{\circ} \mathrm{C}$, as recommended in the material sheet. Considering a different approach for crosslinking (crosslinking in the DSC apparatus), the time is comparable to that specified in the material sheet. The activation energy of EVA crosslinking was calculated as $95.6 \mathrm{~kJ} / \mathrm{mol}$ with a pre-exponential factor $11.121 / \mathrm{min}$ and a $60-\mathrm{min}$ half-life of $109.3^{\circ} \mathrm{C}$. The $E_{a}$ value is consistent with that $(91-107 \mathrm{~kJ} / \mathrm{mol})$ reported by Bianchi et al $[16]$. 


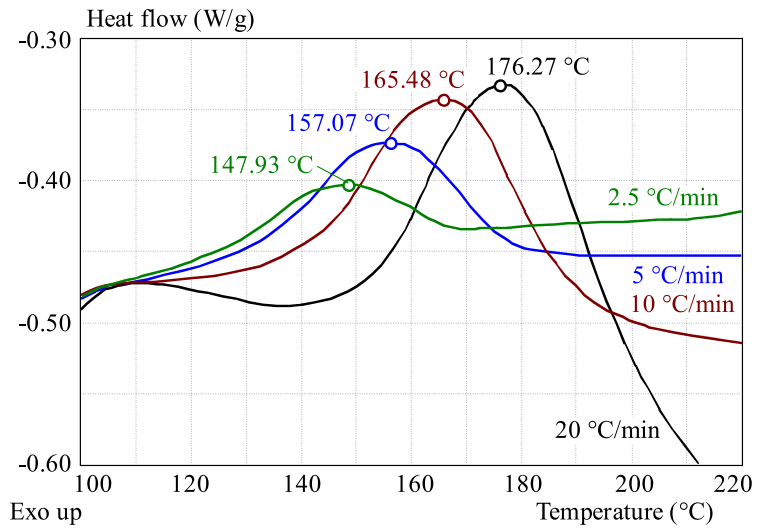

Fig. 3. DSC analysis of the EVA crosslinking reaction at different heating rates

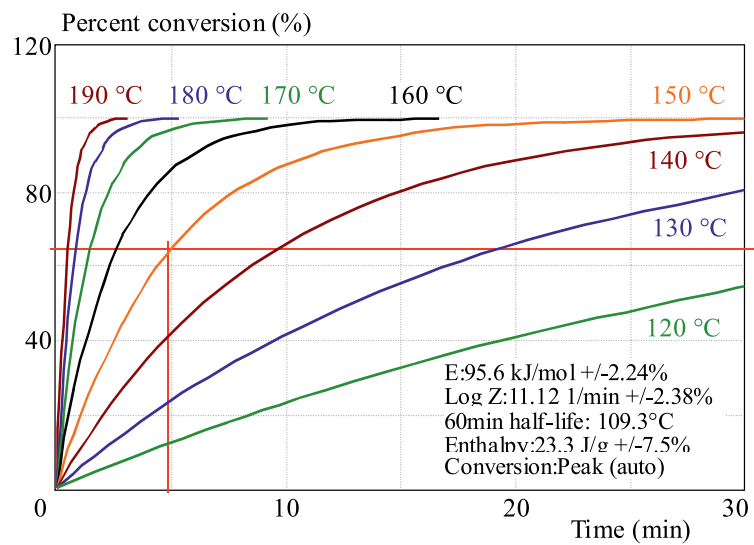

Fig. 4. Kinetic analysis of the EVA crosslinking reaction

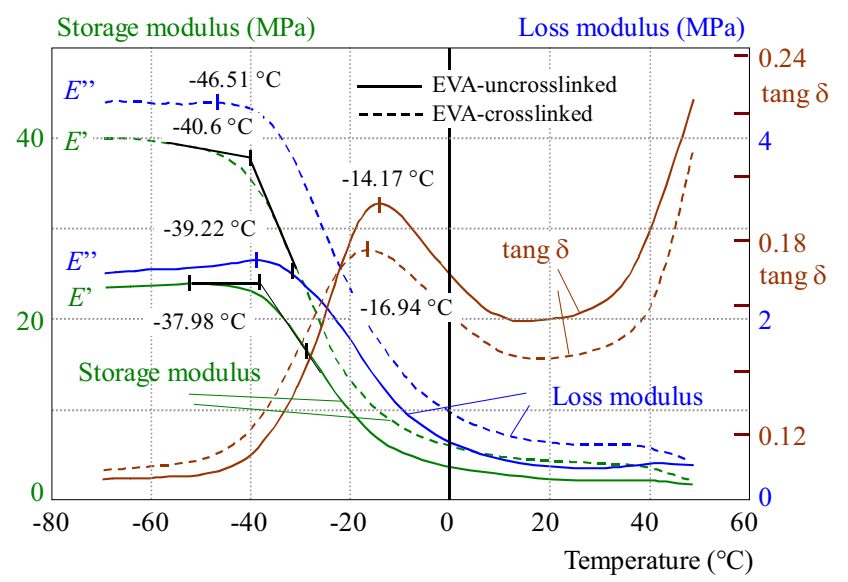

Fig. 5. DMA results of crosslinked and uncrosslinked EVA

It should be noted that temperature and time of crosslinking are just two of several parameters for determining the proper lamination of a photovoltaic module. The fabrication pressure during lamination also plays an important role. Bubbles can behave similar to optical lenses when the lamination is not properly performed. Consequently, bubbles in interaction with sun rays can cause the destruction of solar cells [8].

\subsection{Dynamic mechanical analysis}

Thermogravimetry demonstrated good weight stability over higher operating temperatures. Solar cells can also be exposed to extremely low temperatures (in some cases, even approximately -30 to $-40^{\circ} \mathrm{C}$ ), particularly during the winter season. At such low temperatures, ethylene-vinyl acetate reaches the glass transition temperature [14], and the elastic material becomes solid and notably brittle. Hence, it is very important to monitor the glass transition temperature and the mechanical properties of the EVA film by dynamic mechanical analysis, as it is considered to be the most accurate method for this purpose $[17,18]$.

DMA is a technique in which the deformation of a sample under oscillatory load is measured as a function of temperature, while the sample is subjected to a controlled temperature program. DMA is able to characterize and interpret the mechanical behavior of the material. In short, DMA consists of the application of an oscillating force to a sample and observation of the material in response to that force $[19,20]$. DMA allows division of the material's viscoelastic response into the two components of the complex modulus $\left(E^{*}\right): 1$ ) a real part represented by the storage modulus $E^{\prime}$ [MPa] (ability of the material to return or store energy), and 2) the imaginary part, often called the loss modulus $E^{\prime \prime}[\mathrm{MPa}]$ (ability to lose energy). This separation describes two independent processes in the material, specifically, elasticity and viscosity [21]. The phase angle between those module is defined as the loss factor, $\tan \delta$, and equates to

$$
\tan \delta=\frac{E^{\prime \prime}}{E^{\prime}} .
$$

The DMA results are presented in Fig. 5, where both the crosslinked and the uncrosslinked samples of tested EVA samples are shown. The module, $E^{\prime}, E^{\prime \prime}$, and loss factor, $\tan \delta$ were obtained as functions of temperature during the evaluation.

As obvious from Fig. 5, both module and the loss factor have been changing during the measurement. These changes are related to glass transition, which can be characterized by the glass transition temperature $\left(T_{g}\right)$. The DMA can generally provide three values of the glass transition temperature, which can be analyzed either as a peak maximum of loss modulus $\left(E^{\prime \prime}\right)$, as a peak maximum of loss factor $(\tan \delta)$ or as an onset temperature for the decrease of the storage modulus $\left(E^{\prime}\right)$. Each of these temperatures has physical merit and interpretation. As Foreman et al [17] mention, in the case of the storage modulus, the onset temperature defines the temperature at which the material strength will begin to decrease such that the material may no longer be able to bear a load without deformation. The peak maximum of the loss modulus represents the temperature at which the polymer material undergoes the maximum change in mobility 


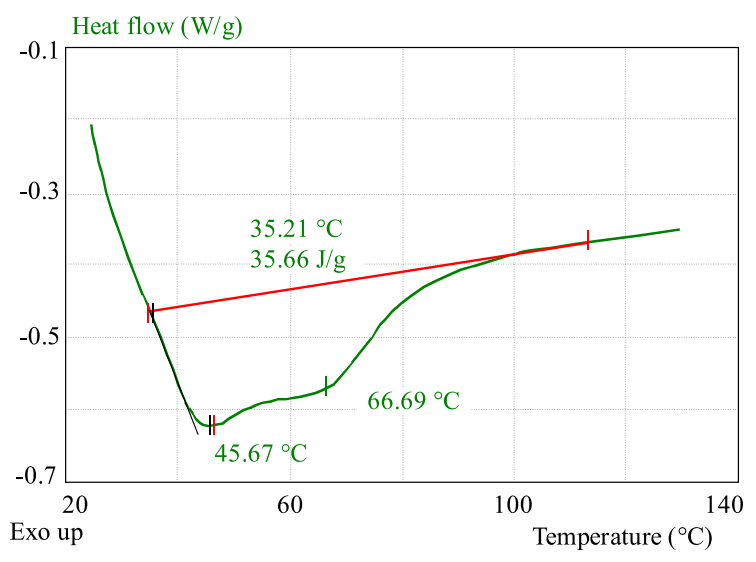

Fig. 6. DSC of crosslinked EVA

of the polymer chains. The peak of the loss factor characterizes the damping characteristics associated with a material.

As Fig. 5 also illustrates, there is a marked increase of the storage modulus (with values almost twice as high) due to crosslinking. Additionally, a slight shift of all analyzed temperatures toward more negative values was observed. The onset temperature for a decrease in the storage modulus, which is the most important property of photovoltaic modules from an operational point of view, is stable at approximately $-40^{\circ} \mathrm{C}$ after crosslinking. This temperature is also often declared by EVA film manufacturers to be the thermal minimum for application. The eventual mechanical stress the photovoltaic module experiences (eg, wind blasts and heavy snow cover) at very low temperatures causes measurable changes in the inner structure much earlier. These changes are expressed by the maximum of the loss factor, the range of which (from higher to lower temperatures) means that the EVA film begins to transform from its flexible state into a brittle state and is no longer able to respond to the mechanical energy caused by the eventual mechanical stress of the module. This energy is subsequently changed in the inner structure of the material into thermal losses that are detected by the high value of $\tan \delta$. In the case of the crosslinked EVA, the maximum value of $\tan \delta$ was observed at a temperature of $-16.9^{\circ} \mathrm{C}$.

\subsection{Differential scanning calorimetry}

The crosslinked sample of copolymer EVA was also analyzed by differential scanning calorimetry to determine the melting temperatures. The results are shown in Fig. 6.

It is obvious that from $30^{\circ} \mathrm{C}$, the DSC recorded the beginning of two overlapping endothermic peaks (with peak maxima at $45.6^{\circ} \mathrm{C}$ and $66.7^{\circ} \mathrm{C}$ ). This phenomenon is the melting of two populations of crystalline perfection. With reference to Agroui et al [12], the lower of those two temperatures refers to melting of imperfect, small crystallites, and this melting occurs due to the integration of vinyl acetate into the polyethylene structure. By comparison, the higher temperature refers to the melting of larger and more regularly formed crystallites in the polyethylene.

\section{CONCLUSION}

Thermogravimetry demonstrated a good weight stability for crosslinked EVA over temperatures ranging from $25^{\circ} \mathrm{C}$ to $90^{\circ} \mathrm{C}$. DMA marked the increasing storage modulus due to crosslinking. The onset temperature of the storage modulus is approximately $-40{ }^{\circ} \mathrm{C}$ after crosslinking, but measurable changes in the inner structure are first observed much earlier. The glass transition temperature (from the $\tan \delta$ peak maximum), in the case of crosslinked EVA, was observed at a temperature of $-16.9^{\circ} \mathrm{C}$. The obtained results show that the EVA film is getting more brittle ( $i e$, more sensitive to mechanical stress when moving toward lower temperatures). Conversely, at higher temperatures, vinyl acetate crystallites begin to melt, even temperatures as low as $46^{\circ} \mathrm{C}$, and polyethylene crystallites begin to melt at $67^{\circ} \mathrm{C}$. These findings are not desirable from an operational point of view. Due to the instability of the encapsulant film, there is a possibility of delamination during operation, and this effect can directly threaten the solar cell itself, and thus the entire photovoltaic module [8]. Although several studies suggest there are more suitable encapsulant materials, eg, silicon-based materials [14,22], ethylene copolymers based on acrylic acids and acrylate [23], EVA films remain dominant in the photovoltaic industry.

\section{Acknowledgments}

This research has been supported by the European Regional Development Fund and the Ministry of Education, Youth and Sports of the Czech Republic under the Regional Innovation Centre for Electrical Engineering (RICE), project No. CZ.1.05/2.1.00/03.0094.

\section{REFERENCES}

[1] SUN, S. H.-TAN, Y.-DONG, W.-ZHANG, H. X.-ZHANG, J. S.: Resistivity Distribution of Multicrystalline Silicon Ingot Grown by Directional Solidification, Journal of Materials Engineering and Performance, Online First(TM) , 3 May 2011.

[2] AHMED, E.-AMAR, M.-AHMED, W.-PILKINGTON, R. D.-HILL, A. E.-JACKSON, M. J. : Laser Annealing of FlashEvaporated CuInSe 2 Thin Films, Journal of Materials Engineering and Performance 15 No. 2 (2006), 213-217.

[3] HOCINE, D.-BELKAID, M. S.-LAGHA, K.: Optimization of SnO2-Si Heterostructure Elaborated by APCVD for Solar Energy Conversion, In Proc. ICREPQ09, Valencia, 2009.

[4] ZHAO, L.-ZUO, Y. H.-ZHOU, C. L.-LI, H. L.-DIAO, H. W.-WANG, W. J.: Theoretical Investigation on the Absorption Enhancement of the Crystalline Silicon Solar Cells by Pyramid Texture Coated with SiNx: H Layer, Solar energy 85 (2010), 530-537, DOI: 10.1016/j.solener.2010.12.020.

[5] ESPINOSA, N.-GARCA-VALVERDE, R.-GARCA-CASCALES, M. S.-URBINA, A.: Towards Low-Cost Manufacturing of Organic Solar Cells: Multi-Criteria Assessment of Fabrication Technologies, In Proc. ICREPQ10, Granada, 2010.

[6] KALOWEKAMO, J.-BAKER, E.: Estimating the Manufacturing Cost of Purely Organic Solar Cells, In press. DOI: 
10.1016/j.solener.2009.02.003. http://

linkinghub.elsevier.com/retrieve/pii/S0038092X09000322.

[7] THEVENARD, D.-PELLAND, S.: Estimating the Uncertainty in Long-Term Photovoltaic Yield Predictions, Solar Energy (2011), In press. DOI:10.1016/j.solener.2011.05.006.

[8] MUNOZ, M. A.-ALONSO-GARCIA, M. C.-VELA, N.CHENLO, F.: Early Degradation of Silicon PV Modules and Guaranty Conditions, Solar Energy 85 No. 9 (2011), 2264-2274, DOI: 10.1016/j.solener.2011.06.011.

[9] KLEMCHUK, P.-EZRIN, M.-LAVIGNE, G.-HALLEY, W.-GALICA, J.-AGRO, S.: Investigation of the Degradation and Stabilization of EVA-Based Encapsulant in Field-Aged Solar Energy Modules, Polymer Degradation and Stability 55 (1997), 347-365.

[10] CZANDERNA, A. W.-PERN, F. J. : Encapsulation of PV Modules using Ethylene Vinyl Acetate Copolymer as a Pottant: A Critical Review, Solar Energy Materials and Solar Cells 43 (1996), 101-181.

[11] ORESKI, G.-WALLNER, G. M. : Aging Mechanisms of Polymeric Films for PV Encapsulation, Solar Energy 79 No. 6 (2005), 612-617, DOI: 10.1016/j.solener.2005.02.008.

[12] AGROUI, K.-MAALlEMI, A.-BOUMAOUR, M.-COLLINS, G.-SALAMA, M. : Thermal Stability of Slow and Fast Cure EVA Encapsulant Material for Photovoltaic Module Manufacturing Process, Solar Energy Materials \& Solar Cells 90 (2006), 2509-2514.

[13] AGROUI, K.-BELGHACHI, A.-COLLINS, G.-FARENC, J. : Quality Control of EVA Encapsulant in Photovoltaic Module Process and Outdoor Exposure, Desalination 209 (2007), 1-9.

[14] KEMPE, M. D.-JORGENSEN, G. J.-TERWILLIGER, K. M.-MCMAHON, T. J.-KENNEDY, C. E.-BOREK, T. T. : Acetic Acid Production and Glass Transition Concerns with Ethylene-Vinyl Acetate used in Photovoltaic Device, Solar Energy Materials \& Solar Cells 91 (2007), 315-329.

[15] American Society for Testing and Materials, 2005. Standard ASTM E698E-05. Standard Test Method for Arrhenius Kinetic Constants for Thermally Unstable Materials Using Differential Scanning Calorimetry and the Flynn/Wall/Ozawa Method. ASTM International, West Conshohocken, United States.

[16] BIANCHI, A.-OLIVEIRA, R. V. B.-FIORIO, R.-MARTINS, J. De N.-ZATTERA, A. J.-CANTO, L. B. : Assessment of Avrami, Ozawa and Avrami-Ozawa Equations for Determination of EVA Crosslinking Kinetics from DSC Measurements, Polymer Testing 27 (2008), 722-729.

[17] FOREMAN, J.-SAUERBRUNN, S. R.-MARCOZZI, C. L. : Exploring the Sensitivity of Thermal Analysis Techniques to the Glass Transition. TA Instruments: Applications Library Search [online]. [cit. 2012-05-04]., 2006, http://www.tainstruments.com $/$ main.aspx? $\mathrm{n}=2 \& \mathrm{id}=181 \&$ main_id $=348 \&$ siteid $=11$.

[18] POLANSKÝ, R.-MENTLK, V.—PROSR, P.—SUŠR, J. : Influence of Thermal Treatment on the Glass Transition Temperature of Thermosetting Epoxy Laminate, Polymer Testing 28 (2009), 428-436.

[19] MENARD, K. P.: Dynamic mechanical Analysis: a Practical Introduction, CRC Press LLC, 1999, p. 205.

[20] MACKENZIE, R. C. : Nomenclature in Thermal Analysis: Part IV., J. Thermal Anal. 13 No. 2. (1978), 387-392.

[21] HATAKEYAMA, T.-QUINN, F. X. : Thermal Analysis: Fundamentals and Applications to Polymer Science, 2nd edition, Chichester: John Wiley \& Sons Ltd., 1999.
[22] MUIRHEAD, I. J.-HAWKINS, B. K. : An Assessment of Photovoltaic Power in the Telstra Network, In Annual Conference of the Australian and New Zealand Solar Energy Society, 1995.

[23] ORESKI, G.-WALLNER, G. M.: Evaluation of the Aging Behavior of Ethylene Copolymer Films for Solar Applications under Accelerated Weathering Conditions, Solar Energy 83 No. 7 (2009), 1040-1047, DOI: 10.1016/j.solener.2009.01.009.

Received 13 November 2012

Radek Polanský (doc, Ing, PhD) was born in Pilsen, Czech Republic in 1978. He received the Master degree in electrical engineering from University of West Bohemia, Pilsen, Czech Republic in 2002 and the PhD degree from the same university in 2005. He joined the Department of Technologies and Measurement at University of West Bohemia in 2004, where he was working as Assistant Professor within the years 2004-2008. He is currently working as an Associate Professor (since 2008) at the same department and as a Senior Researcher at Regional Innovation Centre for Electrical Engineering (since 2012). His main research interests include diagnostics and development of new electrical insulating materials and systems for electrical engineering; application of structural analyses in electrical technology diagnostics and study of aging process of insulating materials. Radek Polanský is a Senior Member of IEEE since 2012 (IEEE Member within the years 2006-2012).

Martina Pinkerová (Ing) was born in Stod, Czech Republic in 1986. She received the Master degree in electrical engineering from University of West Bohemia, Pilsen, Czech Republic in 2010. She is currently studying in doctoral study program "Electrical Engineering and Informatics" (since 2010) and since 2012 working as a head of Laboratory of Thermal Analyses at Kabelovna Kabex a.s. company. Her main research interests include diagnostics of polymers by thermal analyses, development of new plastics compound for cable industry and study of thermal effects inside electrical insulating materials during fire.

Monika Bartůňková (Ing) was born in Stod, Czech Republic in 1986. She received the Master degree in electrical engineering from University of West Bohemia, Pilsen, Czech Republic in 2012. She is currently studying in doctoral study program "Electrical Engineering and Informatics" (since 2012). Her main research interest includes application of thermal analyses in electrical technology diagnostics; she focuses especially on dynamic mechanical analysis and its utilization.

Pavel Prosr (Ing, PhD) was born in Sušice, Czech Republic in 1979. He received the master degree in electrical engineering at the University of West Bohemia, Pilsen, Czech Republic in 2002 and the $\mathrm{PhD}$ degree at the same university in 2005. He has joined the Department of Technologies and Measurement and he has been working as a Research Worker at this university since 2005 and from the year 2012 as a junior researcher at the Regional Innovation Centre for Electrical engineering. His main research interests include aspects of utilization of on-line diagnostic and monitoring system of the power transformers, problems of insulating liquids, degradation of insulating systems and application of structural analysis. 